\title{
Terapeutyczny wymiar sztuki. Przepracowywanie traum choroby i śmierci w sztuce i literaturze - autoterapia artystów na podstawie fotografii Jo Spence, literatury Haliny Poświatowskiej oraz video Billa Violi
}

STRESZCZENIE: Artykuł dotyczy wpływu osobistych traum wybranych artystów na tematykę podejmowaną w pracach artystycznych. Podejmuje próbę znalezienia odpowiedzi na pytanie, czy analizowani artyści byli w stanie przepracować trudne doświadczenie poprzez sztukę i literaturę oraz jakie zabiegi pozwalają dany efekt uzyskać. Przykłady artystów zostały dobrane przy spełnieniu dwóch kryteriów. Pierwszym jest doświadczenie traumy choroby własnej lub bliskich w biografii. Drugim jest używanie formy artystycznej do opracowania emocji związanych z faktami biograficznymi. Omawiani w artykule wybrani artyści, spełniający dane kryteria, to Jo Spence, Halina Poświatowska, Bill Viola. Fototerapia i biblioterapia są punktem wyjścia rozważań o autoterapeutycznym działaniu sztuki i literatury. Jako pierwsze omawiane są traumy związane z chorobą nowotworową i sposób ich przepracowywania w fototerapii Jo Spence. Następnie, omawiane są próby opracowania choroby serca i doświadczenia zbliżania się śmierci przez pisarkę Halinę Poświatowską. Artykuł jest zakończony przykładami twórczości Billa Violi, który traumatyczne doświadczenie utraty matki poddał próbie przemiany oraz nadania nowego znaczenia.

SŁoWA KLUCzowE: biblioterapia, fototerapia, sztuka, literatura, trauma. 


\section{Wprowadzenie}

rtykuł ma na celu zbadanie możliwości przepracowania traumy obec-
nej w biografii wybranych artystów przy użyciu sztuki lub literatury przez nich tworzonej. Wybrani artyści spełniają dwa kryteria - posiadają w biografii wydarzenie traumatyczne oraz umieszczają tematykę owych przeżyć w swojej pracy artystycznej. Do zbadania związków między traumą a sposobem przepracowania wydarzenia przez działania twórcze, używana jest matryca pojęć dotyczących traumy formułowanych przez Hala Fostera oraz klinicznego, psychologicznego znaczenia traumy. Podejmowana jest próba zrozumienia i wypunktowania zabiegów, które używają artyści do przejścia przez traumatyczne przeżycia i sposoby dotarcia do uzdrowienia. Wybrani artyści wykorzystują różne formy wyrazu artystycznego - fotografia w przypadku Jo Spence, film Billa Violi oraz literatura Haliny Poświatowskiej. Metodą przyjętą do badania jest teoretyczna analiza przypadku w podejściu inerpretatywnym immanentno-analitycznym, opartym na fenomenologii doświadczenia źródłowego - używanej w celu wydobycia subiektywnego sensu przeżyć i doświadczeń opisywanych przypadków ${ }^{1}$. Każdy z autorów omawiany jest osobno, jako przykład dla strategii opracowywania traumy w sztuce, wskazanych przez H. Fostera. Artykuł stara się odpowiedzieć na pytanie, czy artyści wybrani na podstawie wyżej wymienionych kryteriów użyli strategii opracowanych przez H. Fostera i jaki efekt uzyskali - dalszej fiksacji na obiekcie traumy czy też ulgi od uciążliwego ładunku emocjonalnego.

Punktem wyjścia do rozważań na temat natury i sposobu przepracowania traum jest psychologiczne rozumienie traumy, w połączeniu z teorią realizmu traumatycznego budowaną przez H. Fostera. Wskazówki, że sam proces przeżywania traumy jest obecny w dziele danego artysty, można odnaleźć w ciągłym powtarzaniu, perseweratywnym umieszczaniu w pracach pewnych tematów lub elementów.

O tej strategii mówił Andy Warhol już w wywiadzie z 1963 roku: „Kiedy raz po raz ogląda się jakiś przerażający obraz, to powoli przestaje

${ }^{1}$ D. Lalak, Życie jako biografia - podejście biograficzne w perspektywie pedagogicznej, Warszawa 2010, s. 239. 
on oddziaływać". Z pewnością to jedna z funkcji powtórzenia, przynajmniej w definicji Freuda: powtarzamy traumatyczne wydarzenie (w rzeczywistych działaniach, snach na obrazach), aby na powrót włączyć je w ekonomię psychiczną i porządek symboliczny. Lecz powtórzenia Warhola nie spełniają tak rozumianej uzdrawiającej funkcji. Nie mają pomóc zapanować nad traumą. Nie pozwalają na stopniowe oddzielenie się od przedmiotu w akcie żałoby, lecz świadczą raczej o obsesyjnej fiksacji na przedmiocie w melancholii².

H. Foster zaznacza, iż jednym z głównych aspektów wyróżniających traumę z innych nieszczęść jest powtarzalność. Można zaobserwować to zjawisko w kategoriach psychiatrycznych, obsesji, fiksacji, przeżywania na nowo obrazów związanych z wydarzeniem przeszłym. W perspektywie sztuki jest to ciągłe przeżywanie aspektu rzeczywistości, pewnego przedmiotu - wydarzenia, które może dziać się w tej chwili, lecz chwili rozumianej jako sytuacji rozciągniętej w czasie - choroby czy też stanu zagrożenia dla jednostki. Trauma jest w tym ujęciu czymś w rodzaju braku możliwości rozdzielenia tego, co jest „rozdarciem” od tego, co nim nie jest. Gdy podmiot zlewa się ze światem zewnętrznym, to co wewnętrzne wylewa się poza podmiot ${ }^{3}$. Realne jest jedno, lecz może ulec symbolizacji przez społeczeństwo i stać się traumą rozumianą i przeżywaną szerzej, traumą społeczną.

Najważniejszą myślą H. Fostera jest spostrzeżenie, iż widz ma doświadczyć traumy przy pomocy wytworu artysty ${ }^{4}$. Nużąca powtarzalność, skupienie się na twarzy, rzeczy, wydarzeniu, które zostaje długo w pamięci widza, sprawia że trudno mu pozbyć się danego obrazu. Zbliża to oglądającego do rzeczywistego poczucia traumy - jest świadkiem wydarzeń, które zostawiają ślad w pamięci. Doświadczenie, namacalne przeżycie jest w swojej istocie traumatyczne. Co więcej, podmiot, który jest w stanie zamrożenia, szoku, przyjmuje za swoją naturę to, co go szokuje, działając w sposób mimetyczny. Powtarzanie obrazu może być jednocześnie obroną przed nim jak i drenowaniem jego znaczenia 5 .

\footnotetext{
${ }^{2}$ H. Foster, Powrót realnego. Awangarda u schyłku XX wieku, Kraków 2010, s. 159.

3 Tamże, s. 161.

4 Tamże, s. 159.

5 Tamże, s. 283.
} 


\section{Traumy choroby nowotworowej i sposób ich przepracowywania w sztuce Jo Spence}

Osoba badana musi spełniać dwa warunki, by zostać zdiagnozowaną z zespołem posttraumatycznym - przeżyć sytuację związaną z bezpośrednim zagrożeniem życia, fizycznej integralności, albo doświadczyć intensywnego przeżycia skrajnego. Drugim koniecznym warunkiem jest przeżycie strachu, silnego lęku czy nawet paniki. Konieczne jest także wskazanie pacjenta na utrzymujący się ciągle lęk związany z tamtym wydarzeniem, nieprzemijające "przeżywanie na nowo" ${ }^{6}$. Wydarzenie może powracać do osoby doświadczającej zespołu stresu pourazowego (ang. posttraumatic stress disorder, dalej: PTSD) w koszmarach sennych. Bezradność wobec ciągle powracającego momentu powoduje wyczerpanie, stan oszołomienia, oziębienia emocjonalnego i w konsekwencji powstaje konieczność zgłoszenia się do specjalisty. Często doświadczenie wiąże się ze zjawiskami „flashbacków”, czyli powracających bardzo realistycznych wspomnień wydarzenia. W niektórych przypadkach silnego stresu pacjent doświadcza uczucia derealizacji, depersonalizacji, czyli zbioru zjawisk związanych z traceniem poczucia tożsamości, mieszania zmysłów, wrażenie "grania w filmie". Ważnym aspektem w omawianiu wydarzeń traumatycznych jest skonkretyzowanie obszarów potencjalnie traumatyzujących dla danej osoby. Należą do nich: katastrofy naturalne (powodzie, huragany, trzęsienia ziemi), katastrofy spowodowane przez człowieka (wypadki, pożary, skażenie środowiska), przemoc i agresja, wojny i działania polityczne (zabijanie, tortury, porwania), agresja w środowisku społecznym (napady gwałty, rozboje), agresja w rodzinie (przemoc fizyczna, psychiczna, gwałty). PTSD dotyczy głównie wydarzeń, które zdarzyły się raz w odróżnieniu od traumy powtarzanej wielokrotnie, lub cyklicznie - reakcje na takie wydarzenia mogą mieścić się także w wielu innych kategoriach diagnostycznych ${ }^{7}$.

Sposób mówienia o chorobie pokazuje odczucia chorych i pozwala zrozumieć ich stan. Świadczy o samopoczuciu w odniesieniu do stanu fizycznego, ale też o poczuciu przynależności do wspólnoty, adekwatno-

\footnotetext{
${ }^{6}$ L. Cierpiałkowska, Psychopatologia, Warszawa 2013, s. 376.

7 Tamże, s. 376-377.
} 
ści, bycia chcianym lub niechcianym, samoocenie, strachu przed śmiercią. Jednocześnie, gdy stan zostanie nazwany konkretną chorobą, może także wywołać ulgę - oto odmieniec staje się pacjentem, a bóle mają przyczynę, nazwę, sposób leczenia. Choroba przychodzi wraz z naruszeniem naturalnego porządku rzeczy - homeostaza organizmu zostaje zaburzona, obcy obiekt pojawia się w ciele lub już obecny uniemożliwia funkcjonowanie, ulega mutacji i przypomina o śmiertelności, która jest tak trudna do przyjęcia w społeczeństwie przemysłowym². W 1990 r. Jo Spence podczas leczenia nowotworu zrobiła we współpracy ze swoim lekarzem serię zdjęć. Fototerapia, ponieważ tak mówiła o cyklu zdjęć opowiadającym o jej chorobie, nie miała na celu przedstawić straszne skutki raka, zniszczone ciało czy szokować brakiem jednej piersi. Chciała stworzyć narzędzia, do wizualnego pokazania sposobów mówienia o władzy czy wstydzie ${ }^{9}$. Autorka posłużyła się medium fotografii, by opowiedzieć o swoich intymnych odczuciach - o tym, jak się czuje, gdy obserwuje swoje zmieniające się ciało, reakcje innych i pobyt na oddziale onkologicznym. W pracach można odnaleźć etykiety, które nakładano na nią z powodu choroby. Pojawia się słowo „monster” na fotografii trzeciej - „exiled” z cyklu „Narratives of Dis-ease” ${ }^{10}$. To silnie negatywnie nacechowane słowo tworzy obraz osoby chorej, którą ludzie postrzegają w określony, niepełny sposób. Nie dość, że artystka wykończona jest chorobą, pokazuje także zmęczenie wynikające z poczucia bycia wyrzutkiem, potworem, kimś kto może potencjalnie zarazić czy też wywołuje uczucie obrzydzenia. Artystka została przez chorobę pozbawiona możliwości funkcjonowania uwięziona na oddziale, nie może podejmować decyzji, czuje, że zabierana jest jej tożsamość. Buntuje się przeciwko dotychczasowym, dozwolonym w dyskursie społecznym, sposobom przedstawiania kobiet: w kontekście mężczyzny, z obiema zdrowymi piersiami ${ }^{11}$. Jo Spence zmarła w 1992 r., dwa lata po rozpoczęciu cyklu.

8 S. Sontag, Choroba jako metafora. AIDS i jego metafory, Kraków 2016, s. 12.

9 M. Meskimmon, The Monstrous and the Grotesque: On the Politics of Excess in Women's Self Portraiture, „Make: the Magazine of Women's Art” 1996, s. 6-11.

${ }^{10}$ J. Spence, T. Sheard, Narratives of Dis-ease (Exiled) [il.], [w:] The Camerawork Essays: Context and Meaning in Photography, red. Jessica Evans, Sandy Weiland, Barbara Hunt, Londyn 1997, s. 259.

11 M. Meskimmon, dz. cyt., s. 6-11. 
Choroba jest nocną półkulą życia, naszym bardziej uciążliwym obywatelstwem. Od dnia narodzin każdy z nas posiada bowiem jakby dwa paszporty - przynależy zarówno do świata zdrowych, jak i do świata chorych. I choć wszyscy wolimy przyznawać się tylko do lepszego z tych światów, prędzej czy później, chociażby na krótko, musimy też uznać nasz związek i z tym drugim ${ }^{12}$.

S. Sontag pisze o raku jako o jednym z najbardziej namacalnych, fizycznych i nieromantycznych przypadłości. W świadomości mas rak kojarzony jest ze śmiercią społeczną - niszczy życie rodzinne, grozi utratą pracy, pożegnaniem z karierą.

Najwcześniejsza dosłowna definicja raka określa go jako narośl, guz, wypiętrzenie, nazwa zaś choroby - od greckiego karkinos i łacińskiego cancer, które oznaczają kraba bądź raka - ma według Galena źródło w podobieństwie nabrzmiałych żył otaczających guz do odnóży kraba, nie zaś w tym, jak przypuszcza błędnie wiele osób, że gdy dochodzi do przerzutów, choroba pełza niczym krab bądź rak ${ }^{13}$.

Nawet nazwa posiada w sobie coś groźnego, zagrażającego, wygląd narośli jest przerażający, a ból towarzyszący chorobie nie do zniesienia. Ponadto, rak nie ma w sobie ani grama romantyczności, wiązanej bardziej z gruźlicą - uważa się, że jego przyczyną są niedopuszczone emocje, namiętności, utajony popęd seksualny, któremu nie daje się ujścia ${ }^{14}$.

Wyłania się obraz osoby pozbawionej spontaniczności, sztywnej, pełnej gniewu, który trzyma głęboko w sobie. Zdławiona agresja i popęd seksualny stają się wrogami osoby chorej, i jakby w zemście za zakaz wyjścia pozbawiają ją zdrowia. Jest to symboliczna „zdrada ciała” ${ }^{15}$. Warto dodać do obrazu osoby chorej zrezygnowanie, utratę nadziei, czekanie na śmierć. W miarę postępu choroby rezygnacja się pogłębia, a pacjent zostaje z poczuciem wydrążenia, pustki. Wizerunek ten koresponduje

\footnotetext{
12 S. Sontag, dz. cyt., s. 7.

13 Tamże, s.13.

14 Tamże, s. 25.

15 Tamże, s. 44.
} 
z teorią, iż choroba oddaje charakter chorego, jest także konsekwencją, produktem jego woli.

Choroba objawia się jako zorganizowane ciało - pisał Schopenhauer a obecność choroby oznacza, iż sama wola jest chora. Wyzdrowienie zależy od tego, czy zdrowa wola narzuci „rządy dyktatorskie, aby zdławić bunt" chorego ciała ${ }^{16}$.

W tym ujęciu choroba widnieje także jako kara - za to, iż chory bał się ze sobą skonfrontować, zajrzeć w siebie i dać upust emocjom. Może czuć się winny, jakby wykreował raka swoim charakterem, uczynił siebie chorym. Uświadomienie sobie okrutności tego twierdzenia wzbudza ogromny niepokój i niezgodę, jednak chociażby rak wynikający z palenia papierosów łączy się w wyobrażeniu z osobami znerwicowanymi, a więc wpasowującymi się w ten model. Wiele osób przekonanych jest o tym, że to jest wina chorych, że zachorowali. Wielokrotnie stwierdzano powiązania pojawienia się raka z ciężkimi przeżyciami, z traumami, zaburzeniami lękowymi, depresją, nerwicą ${ }^{17}$.

Tekst Sontag posłużył do próby wcielenia się w Spence, zrozumienia, czym tak naprawdę była jej choroba, jaką funkcję miała spełnić fototerapia oraz jakie znaczenie ma w tym samo zjawisko traumy. Słowo „monster” wypisane na klatce piersiowej Spence było reakcją na odbiór społeczny artystki jako osoby chorej. Traumą jest tu nie tylko choroba, ale także to, co się z nią wiąże - fantazje społeczne na temat nowotworu, odbiór artystki jako chorej osoby, jej własne fantazje i trudności dotyczące faktu bycia chorą. Codzienne spotkania z własną niesprawnością, ciałem, które to staje się coraz bardziej owładnięte chorobą. Podmiot na poziomie psychologicznym jest naocznym świadkiem swojego cierpienia i może podać jego świadectwo swoją osobą. Staje się więc zarówno przeżywającym, jak i obserwatorem ${ }^{18}$. W rozumieniu naukowym, traumatyczny mógł okazać się moment diagnozy, uświadomienia grożącej śmierci,

\footnotetext{
16 Tamże, s. 47.

17 Tamże, s. 54.

18 H. Foster, dz. cyt., s. 327.
} 
czyli przeżyć z pogranicza ${ }^{19}$. Próba odzyskania tożsamości w fototerapii implikuje poprzedzającą wydarzenia utratę.

Chory na raka jest w rozumieniu społecznym osobą znerwicowaną i nieszczęśliwą, która nie potrafi wyzwolić swoich prawdziwych emocji, a czasem nie ma nawet do nich dostępu. Przez swoją nadmierną emocjonalność traci kontrolę nad swoimi impulsami, a ciało buntuje się przeciwko niej. Rak jest wytworem jej woli, więc osoba staje się swoim napastnikiem, pozbawionym walki człowiekiem o zdeformowanym ciele. Osoba chora staje się wykluczona - bez kariery, życia rodzinnego, zamknięta na oddziale. Posiadająca wyrok śmierci, który jest nieubłagalny ${ }^{20}$. Obraz ten staje się prześladowcą Spence. Przeżyć artystki inny człowiek może doświadczyć, zgodnie z poglądem Fostera, jako odbiorca sztuki. Powracające wspomnienie w postaci zniekształconej piersi, nie daje się wyrzucić z pamięci. Tak więc widz doświadcza tego, co prześladowało artystkę - zmian fizycznych, oraz sam konfrontuje się z jej odbiorem społecznym. Obecne na obrazach batony, elementy z popkultury nawiązujące do piersi, idealne maski, słodkie dziecięce misie wprowadzają powoli w stan coraz większego bólu ${ }^{21}$. Wraz z kolejnym obrazem doświadczenie powtarzalności kontrastu, silnych emocji wywołuje pogłębienie traumy. Dla samej autorki, podzielenie się z innymi odczuwaniem zaistniałej sytuacji jest związane z docelowym uczuciem ulgi. Fototerapia jest możliwa z powodu funkcji zdjęć - prace nie mają za zadanie obrzydzić widza, zszokować, lecz oddać to, co najgłębsze, umożliwić dzielenie się doświadczeniem, poszukiwaniem zagubionej tożsamości i w efekcie przynoszą autorce spokój.

\section{Autoterapia i biblioterapia śmiertelnej choroby serca w Opowieści dla przyjaciela Haliny Poświatowskiej}

Poezja autorstwa Haliny Poświatowskiej stanowi przykład innej formy artystycznej, umożliwiającej twórcy oswojenie własnej traumy. Życie polskiej poetki kończy się bardzo szybko - Poświatowska zmarła w wieku

\footnotetext{
19 L. Cierpiałkowska, Psychopatologia, Warszawa 2013, s. 376.

20 S. Sontag, dz. cyt., s. 54-57.

${ }^{21}$ J. Spence, T. Sheard, dz. cyt.
} 
32. lat, wskutek nieudanej operacji serca w $1967 \mathrm{r}^{22}$. Problemy zdrowotne, związane z kondycją serca, były stałym elementem jej życia, a lęk o zdrowie i poczucie swojej nadchodzącej śmierci jest motywem powtarzającym się w poezji. Poetka próbuje opracować traumę życia z chorobą przez pracę nad różnymi rodzajami tekstów literackich. Próbuje także przekształcić ból w przeciwieństwo śmierci - przemieniając go w potencjalną siłę kreatywną. Głównymi motywami poezji Poświatowskiej jest naznaczona potencjalnym rozpadem cielesność, zmysłowość w odbieraniu rzeczywistości, obecne są szczególnie romantyczne aspekty miłości. Uczucia uniesień miłosnych połączone ze śmiercią i doświadczeniami płynącymi z chorego ciała, odgrywają w poezji rolę trzech głównych kluczy, dzięki którym możliwe jest zrozumienie sposobu przeżywania traumatycznej choroby. Uwidacznia się również stosunek do równie trudnej dla Poświatowskiej perspektywy całkowitego jej znikania, zarówno ze świata fizycznego, jak i wewnętrznego osób, które są poetce bliskie, a także sposobem na pogodzenie się ze śmiercią innych. Wyraźnie można zaobserwować taki sposób przeżywania śmiertelności w Opowieści dla przyjaciela autorstwa Poświatowskiej:

Ilekroć myślę o nim, zaciskam zęby, tak myślę o nim myśląc o ziemi. Czy stała się przez to żyźniejsza, czy wypiękniała? W miejscu jego śmierci, na urwistym górskim zboczu, zakwitły małe fioletowe krokusy, zbocze pociemniało od kwiatów, które jeszcze wtedy istniały tylko w wyobraźni tej żyznej, bujnej ziemi. Dlaczego tak hojnie rodzi, czemu bezmyślnie uśmierca? Pytania naiwne, dręczące, na które nikt i nigdy nie znalazł odpowiedzi ${ }^{23}$.

W twórczości poetki znaczący jest egzystencjalny lęk przed śmiercią, rozstaniem, rozpadem ciała, końcem, zamaskowany w sentymentalnych, zmysłowych opisach. Przedmiot lęku zostaje opracowany poprzez pisanie o nim, staje się uniwersalną opowieścią dla innych, którzy w ten sposób mogą współdzielić traumatyczne doświadczenie artystki.

22 B. Dumowska, Anegdota o istnieniu, wokół liryków Haliny Poświatowskiej, „Pamiętnik Literacki: czasopismo kwartalne poświęcone historii i krytyce literatury polskiej” 1986, nr 77/2, s. 137.

${ }^{23}$ H. Poświatowska, Opowieść dla przyjaciela, Kraków 2009, s. 204. 
Sentymentalizm ten czytać można jako jedną ze stylistycznych masek lęku, jako porażkę mowy, która za przedmiot ma traumę (własnej) śmierci. Ta zaś jest bardzo silnie związana z parametrem przestrzennym, już zresztą na poziomie frazeologii, która to ujawnia przecież dobitnie powiązanie zgonu z miejscem (pogrzebanie w ziemi, miejsce wiecznego odpoczynku) ${ }^{24}$.

Choroby serca uważane są za słabość, nie za coś, co trzeba tabuizować. Nie wywołują zażenowania, odrazy ${ }^{25}$. Są rodzajem mechanicznego urazu każdy nadmierny ruch fizyczny i duże emocje mogą wywołać katastrofę. Własna autoterapia w wykonaniu poetki nosi znamiona biblioterapii. Biblioterapia jest jednak nastawiona na odbiorcę dzieła literackiego, w którym autor jest tylko kreatorem materiału leczącego lub wspomagającego inne jednostki. W zależności od potrzeby czytelnika i rodzaju problemu, biblioterapia może służyć jako element rozwojowy czy też stricte leczący w zaburzeniach emocjonalnych. Niektórzy badacze przyjmują, iż można rozróżnić zastosowanie biblioterapii jako terapię czytelniczą w wersji klinicznej oraz rozwojowej ${ }^{26}$. W przypadku Poświatowskiej, technika klinicznego oddziaływania na pacjenta jest mniej istotna - bardziej przyjmuje tu rolę katharsis - przeżycia korekcyjnego emocjonalnie. Jest ona wytwórcą dzieła literackiego, lecz jednocześnie sama jest odbiorcą dobroczynnego działania terapeutycznego, poprzez nawiązania autobiograficzne. Biblioterapia może być rozumiana jako:

metoda rozwoju osobistego, w której za pomocą odpowiednio dobranych materiałów czytelniczych i/lub ich substytutów, wspiera się funkcjonowanie człowieka w sferze emocjonalnej, intelektualnej oraz społecznej ${ }^{27}$.

${ }^{24}$ K. Szalewska, Przestrzeń choroby - miejsce biografii. Kartografia psychosomatyczna $w$ „Opowieści dla przyjaciela” Haliny Poświatowskiej, za: E. Konończuk, E. Sidoruk (red.), Przestrzenie geo(bio)graficzne w literaturze, Białystok 2015, s. 221.

25 S. Sontag, dz. cyt., s. 12.

${ }^{26}$ M. Cyrklaff, Biblioterapia w edukacji z zakresu profilaktyki uzależnień i promocji zdrowia, Toruń 2014, s. 70.

27 Tamże, s. 71. 
Funkcje, które spełnia obejmują trzy obszary oddziaływań: interakcje w sferze intelektu, kognitywne, w skład których wchodzi funkcja informacyjna, kształcąca, filozoficzno-społeczna. Drugim obszarem jest funkcja emotywna - estetyczna, emocjonalna, kompensacyjna, identyfikacyjna, partycypacyjna, prestiżowa, terapeutyczna, relaksacyjna, rozrywkowa, hedonistyczna oraz ewazyjna. Trzecim, ostatnim obszarem jest funkcja motywacyjna - wychowawcza, inspirująca, utylitarna ${ }^{28}$. W tym specyficznym wypadku, Poświatowska korzysta najbardziej z dobroczynnego wpływu drugiego omawianego obszaru - funkcji związanej z przeżyciem emocjonalnym. Nacechowana dużą delikatnością, czułością i sentymentalizmem proza autorki pozwala na identyfikację zarówno czytelnikowi z autorką i postaciami przez nią kreowanymi, jak i samej autorce poprzez identyfikację z bohaterami pozwala w katartyczny sposób bezpiecznie wyrazić własny ból.

Ten łańcuch identyfikacyjny tworzy specyficzną sieć wsparcia, w przeżywanym wspólnie uniesieniu powodowanym dotykaniem tematów egzystencjalnych, szczególnie trudnych dla autorki. Faktem spajającym jej przeżycia z czytelnikiem, jest bycie śmiertelnym - jest to doświadczenie dotykające każdego człowieka i u każdego wiąże się z lękiem.

Człowiek jest wprzęgnięty w świat przyrody, ale nie bez reszty, bowiem jest zdolny do transcendowania jej. Jego ciało ulega systematycznemu niszczeniu, co w efekcie doprowadza do śmierci organizmu, zaś dzięki duchowości jest świadomy - przynajmniej w niektórych okresach życia - że umrze. Jest to jednak świadomość dość dziwna, jakby zamazana, gdyż doświadczenie uczy, że umiera ktoś bliski lub znajomy, ale nie my sami. Inaczej mówiąc, człowiek nie doświadcza własnej śmierci bezpośrednio, ale poprzez warunki i otoczenie w jakim żyje. Ponieważ to doświadczenie jest bliżej nieokreślone, budzi lęk ${ }^{29}$.

Poprzez graniczne doświadczenie Poświatowskiej, czytelnicy mogą podjąć temat własnej śmiertelności, przy pomocy funkcji identyfikacyjnej i ka-

${ }^{28}$ Tamże, 67-68, za: J. Andrzejewska, Kultura czytelnicza jednostki jako program edukacji czytelniczej i przedmiot badań, „Studia o Książce. Ogólnopolski organ szkół wyższych" 1989, t. 18, s. 47-48.

${ }^{29}$ J. Makselon, Specyfika postaw wobec śmierci, „Studia Philosophiae Christianae” 1981, nr 17/2, s. 121. 
tartycznej oddziaływań biblioterapeutycznych. Autorka w tym obszarze jest jednocześnie odbiorcą - autoterapeutycznie obniża lęk, upodabniając postaci w Opowieści dla przyjaciela do siebie samej. W ten sposób, obniżenie lęku poprzez twórczość, obejmuje zarówno autoterapię, jak i umożliwia biblioterapeutyczne opracowanie własnych traum czytelnikom. Wizerunek osoby chorej na serce - delikatnej i naznaczonej tragedią, jest łatwy dla czytelników do identyfikacji - nie jest tak bardzo obciążony społecznym wykluczeniem jak rak czy AIDS $^{30}$.

\section{Poszukiwanie sensu cierpienia w sztuce autorstwa Billa Violi}

Trauma, jako specyficzny, wyjątkowo silny rodzaj cierpienia jest szczególnie problematyczna w uznaniu i przyjęciu jej przyczyn. Może być trudno rozumieć wydarzenie o takich konsekwencjach, jako przypadkowe. Mogą powstawać fantazje o chorobie jako o karze, odpowiedzialności chorego $^{31}$. Artystów opisywanych łączy jedna kwestia - wyrazisty początek cierpienia, ale brak jego końca. Każdy opisany artysta radził sobie z własną traumą w pracach artystycznych, co pozwalało mu z nią żyć, ale nie pozwalało jej się pozbyć. Specyficzną cechą traumy jest powtarzalność - ciągłe wracanie myślą i doświadczeniem do danego wydarzenia, którego nie da się wyciąć z biografii ani zmienić32. Odruchowo człowiek szuka sposobu, żeby nadać takiemu wydarzeniu wyższy sens. Bill Viola jest artystą, znanym jako twórca związany z obrazowaniem video, wykorzystujący najnowsze dostępne techniki.

Artysta zajmuje się głównie cierpieniem - lecz Violę interesuje cierpienie pod kątem jego znaczenia, sensu duchowego. Jest to często cierpienie martyrologiczne - męczennictwo ma często kształt czegoś pożądanego, koniecznego do szczęścia, uzależniającego.

Od wczesnej młodości przyciągały mnie piękne rzeczy: stare drzewo na tyłach domu, światło wieczoru. Kiedy dorosłem, jako student

\footnotetext{
30 S. Sontag, dz. cyt., s. 112.

31 Tamże, s. 62

${ }^{32}$ H. Foster, dz. cyt., s. 284-285.
} 
stałem się bardzo oporny wobec wszystkiego, co było piękne, bo moja mama lubiła ładne rzeczy. Wiedziałem, że jeśli mojej mamie podoba się jakaś moja praca, to nie może to być dobra sztuka. Dziś myślę zupełnie inaczej. Patrzę na ludzi, którzy doświadczyli najróżniejszych cierpień. Zwłaszcza starszych ludzi, bo gdy żyjesz długo na świecie będziesz cierpiał. Życie jest trudne. To naturalna tendencja, że gdy się starzejemy chcemy otaczać się rzeczami pięknymi i komfortowymi. Oczywiście wszelkie nauki duchowe ostrzegają nas przed tym, każą nam bardzo uważać, być świadomym tego, ale też mówią, że być szczęśliwym to dobra rzecz, nie zła. Cierpienie może być jak narkotyk, można się od niego uzależnić. Są ludzie, którzy uwielbiają czuć się żałośnie ${ }^{33}$.

Pojawia się więc nowa perspektywa: trauma nie musi być wydarzeniem, które trzeba przepracować w formie walki ze wspomnieniami, doświadczeniami, ale także może oznaczać korzyści płynące z cierpienia - życie człowieka naznaczonego ciężkim doświadczeniem jest wyjątkowe. Cierpienie upodla, ale także wznosi na wyżyny. Viola proponuje nowy sposób pojmowania piękna, które zestawia ze śmiercią czy też balansowaniem między życiem a śmiercią:

[...] jeśli idzie o życie to najpiękniejszym obrazem jaki widziałem kiedykolwiek była martwa twarz mojej matki. Nigdy jej nie zapomnę. Była szara, blada, miała zapadnięte oczy, rozchylone usta z których wyciekała żółta ciecz. A ja zobaczyłem najpiękniejszą twarz. Mój brat, który nie jest artystą, przeżył to zupełnie inaczej, wręcz przeciwnie. Mówił, że to najstraszniejszy widok. Ja zobaczyłem piękno ${ }^{34}$.

Praca The Passing (1991) opiera się na doświadczeniach Violi związanych z chorobą i śmiercią matki. Wydarzenie śmierci bliskiej osoby jest niewątpliwie jednym z najbardziej bolesnych wydarzeń w życiu człowieka. Video pokazuje matkę Violi, utrzymywaną przy życiu przez aparaturę medyczną. Ostatnie chwile, ostatnie dni jej życia, nagrane za jej pozwo-

${ }^{33}$ P. Reiter, B. Viola, Ludzie nadal trochę boją się sztuki wideo. Rozmowa [online]. Poznań 2016 [dostęp 9 maja 2016]. Dostępny w World Wide Web: http://www.obieg. $\mathrm{pl} /$ wydarzenie/2180.

34 Tamże. 
leniem, są zupełnie nowym sposobem obrazowania tak traumatycznej chwili. Inaczej, niż w przypadku innych wspomnianych artystów, B. Viola zwraca uwagę na potencjalne doświadczenie piękna płynące $\mathrm{z}$ sytuacji, która może traumatyzować. I chociaż nawiązuje do sytuacji dramatycznych, dramat ten przeżywany jest w silnych emocjach, żalu, ale także wzniosłości. Oprócz matki, w video znajdują się ujęcia samego artysty, śpiącego, stojącego do połowy w wodzie.

Także kolejne kadry znajdują wyraźne zakorzenienie we wspomnieniach artysty. Po niemal nieczytelnych obrazach mających przywoływać złudzenia optyczne, które interesowały artystę w wieku młodzieńczym, na ekranie ukazuje się motyw pojawiający się w różnych wariantach zarówno we wcześniejszych, jak i w późniejszych realizacjach artysty: do wody wpada ciało mężczyzny, by potem unosić się swobodnie w wodzie, aż do momentu, kiedy jej powierzchnia odzyska spokój ${ }^{35}$.

Wraz z napięciem związanym ze śmiercią bliskiej osoby, przychodzą do artysty sceny z przeszłości, których uczuciowym powtórzeniem jest sytuacja artysty.

Scena ta odwołuje się do innego wspomnienia z dzieciństwa. Bill, mając sześć lat, uległ wypadkowi podczas zabawy z kuzynami. Młodzi chłopcy wskakiwali do wody tak, by trafić w światło dużej dętki, która tuż przed zanurzeniem służyła im za rodzaj koła ratunkowego. Podczas jednego ze skoków nieumiejący pływać B. Viola nie zdążył uchwycić się dętki i zaczął tonąć. Chociaż został uratowany nie ponosząc uszczerbku na zdrowiu, doświadczenie to było dla niego traumatyczne i jednocześnie posiadało konotacje doświadczenia duchowego. Światło padające na taflę jeziora, rośliny i zwierzęta oraz być może także obrazy generowane przez niedotleniony mózg tworzyły razem fascynującą kompozycję. Doświadczenie sprawiło, że pragnienie pozostania w głębinach dłużej było silniejsze niż strach przed utonięciem ${ }^{36}$.

35 A. Pitrus, The Passing: obrazy z soli i pieprzu, „Media - Kultura - Komunikacja Społeczna" 2013, T. 9, s. 167.

36 Tamże, s. 167. 
Twórca nie narzuca jednak żadnych interpretacji. Posiłkując się wydarzeniami ze swojego życia, przywołuje piękno jako odbicie, nieodłączną część cierpienia.

Również kadry ukazujące matkę Violi i jego nowonarodzonego syna zderzone są ze sobą bezpośrednio. Ona - ukazana jest jeszcze w ostatnich chwilach spędzonych w domu, cierpiąca, ale zachowująca wymiar tego cierpienia jeszcze możliwy do wyobrażenia, ludzki. Głowa spoczywa na poduszce, kołnierz nocnej koszuli obszyty jest koronką... Dziecko także cierpi: krótkie ujęcie zrealizowane zostało tuż po jego wyjściu z łona. Chłopiec ma zamknięte oczy, być może jeszcze nie widział światła, którego matka artysty już nie zobaczy ${ }^{37}$.

Mając wgląd w biografię B. Violi, można postawić tezę, iż tematyka narodzin, woda, wychodzenie i wchodzenie do podwodnego świata, powodowana może być przez traumę z dzieciństwa. Okres ten stanowi dla artysty podkreślany wielokrotnie fundament tego, kim jest teraz, oraz zestawiony jest z traumą śmierci. W obu sytuacjach jest to moment przejścia, cierpienia związanego z wchodzeniem w nową sytuację - życia lub śmierci. Prawdopodobnie to właśnie jest najważniejszym elementem do interpretowania traumy w przeżyciu artysty - jest to dla niego niezbędny czynnik przejścia do „nowego” i dzięki temu zyskuje sens. Musi zaistnieć, by pojawił się nowy stan - umysłu, emocji czy nawet śmierci.

Kulminacyjny moment pojawia się tuż po wspomnianej panoramie ukazującej ostatnie chwile życia matki artysty. W kadrze pojawia się stół udekorowany kwiatami, na którym znajdują się: lampa, kubek oraz kartka z notatkami. Przy stole puste krzesło. Ta minimalistyczna kompozycja już po chwili ujawnia swoją prawdziwą naturę: oto bowiem przekonujemy się, że cały pokój znajduje się pod wodą, która zaczyna gwałtownie burzyć się, doprowadzając w konsekwencji do zniszczenia scenografii [...] Ostatnie ujęcie to ponownie obraz samego Violi, którego ciało opadło na dno zbiornika ${ }^{38}$.

\footnotetext{
37 Tamże, s. 168.

38 Tamże, s. 169.
} 
Dla prac Violi niezwykle istotnym tematem są żywioły. Woda przedstawiana jest zarówno jako zagrażająca życiu, jak i oczyszczająca. Niebezpieczna sytuacja zalania wodą całego pokoju, w perspektywie artysty staje się azylem bezpieczeństwa. Śmierć jest ukazana jako oczyszczenie, uwolnienie od cierpienia, udanie się w inny stan świadomości. Jest to także sposób na przepracowywanie traumy, odsunięcie od siebie myśli o przyziemności, nadawanie sensu czy też przerażenia śmiertelnością. Viola pragnie podzielić się z odbiorcami doświadczeniem mieszania się piękna z brzydotą ${ }^{39}$. Gdy cierpienie zyskuje sens, jest usprawiedliwione, trauma i powtarzalność zespala się z chęcią powtarzania czegoś, co jest piękne. Nie jest to jednak turpistyczne zachwycanie się martwym obiektem - do nadania sensu potrzebna jest duchowość nadająca wymiar katharsis. Poszukiwanie transcendencji jest powszechnym aspektem wszystkich religii ${ }^{40}$. Ból może pełnić rolę transformującego, zmieniającego właściwości człowieka. W tym kontekście, walka z traumą może się sprowadzać do zniwelowania bólu, który jest konieczny dla zmiany. Dlatego też praca stanowi nową perspektywę dla rozważań na temat traumy. Sensem traumy staje się transformacja - poprzez ból, opinie innych, okrutne traktowanie przez społeczeństwo, człowiek staje się inny, bardziej złożony, wrażliwy. B. Viola daje możliwość nadania sensu cierpieniu ${ }^{41}$.

\section{Podsumowanie}

Artyści wykonują wiele różnych zabiegów wzbudzenia w odbiorcy poczucia traumy, w celu wywołania w odbiorcy doświadczeń podobnych do przeżyć twórcy. Język sztuki w porównaniu do języka nauki przyjmuje podobne i zarazem różne sposoby mówienia o traumie. Analizowane przypadki indywidualne pokazują, iż badani użyli niektórych wskazanych przez H. Fostera strategii opracowywania traumy w sztuce. Każdy z wybranych artystów zastosował do wyrażenia przeżyć inny zabieg: uderzenie w emocje odbiorcy, powtarzalność tematu lub obrazu traumatycznego, wywołanie doświadczenia choroby w odbiorcy. Elementami

\footnotetext{
39 P. Reiter, B. Viola, dz. cyt.

${ }^{40}$ R. Levis, S. I. Levis, The Power of Art, Thomson Learning, New York 2009, s. 132.

${ }^{41}$ A. Pitrus, dz. cyt., s. 167.
} 
leczącymi jest także doświadczenie katharsis i możliwość identyfikacji, umożliwiającej zmniejszenie cierpienia zarówno w artyście, jak i w odbiorcy. Jednocześnie, trauma pozwala na przemyślenie dotychczasowego sposobu rozumienia życia i pobudza do nadawania sensu cierpieniu. Poświatowska, Viola oraz Spence przekazują swoje doświadczenie, lecz nie odpowiadają na pytanie, czy przepracowanie traumy jest możliwe i transformuje człowieka w kogoś innego, odmienionego. Viola uznaje, iż moment doświadczenia cierpienia jest jednocześnie możliwością doświadczenia piękna i transformacją człowieka w nową jednostkę ${ }^{42}$. Cierpienie może przychodzić z wewnątrz, jak choroba, czy też z zewnątrz, jak oprawca. Jednakże trauma równa wszystkich - cierpienie ludzkie wynika z podobnych powodów, szczególnie to, które związane jest z chorobą czy zetknięciem z własną śmiertelnością ${ }^{43}$. Nie można jednoznacznie odpowiedzieć na pytanie, czy da się uzyskać uzdrowienie i przepracować bolesne doświadczenia przez sztukę, lecz istnieją zabiegi wykonywane przez artystów, które przybliżają do efektu ${ }^{44}$. Analizowani artyści użyli określonych czynników, służących przepracowaniu traumy. W pracy Spence można wyróżnić wspólne przeżywanie bólu z widzem, w utworach Poświatowskiej identyfikację z bohaterem oraz katharsis, a w dziełach Violi również katharsis, a także przeformułowanie bólu w doznanie estetyczne. Czynnikiem łączącym artystów jest powtarzalność i perseweratywność jako element przeżywania i przekazywania traumatycznego doznania fiksacja na zdarzeniu traumatyzującym.

\section{Bibliografia}

Andrzejewska Jadwiga, Kultura czytelnicza jednostki jako program edukacji czytelniczej i przedmiot badań, „Studia o Książce. Ogólnopolski organ szkół wyższych" 1989, t. 18, s. 47-48.

Cierpiałkowska Lidia, Psychopatologia, Warszawa 2013.

Cyrklaff Magdalena, Biblioterapia w edukacji z zakresu profilaktyki uzależnień i promocji zdrowia, Toruń 2014.

\footnotetext{
${ }^{42}$ P. Reiter, B. Viola, dz. cyt.

${ }^{43}$ S. Sontag, dz. cyt., s. 10.

${ }^{44}$ H. Foster, dz. cyt., s. 285
} 
Dumowska Bogumiła, Anegdota o istnieniu, wokół liryków Haliny Poświatowskiej, „Pamiętnik Literacki: czasopismo kwartalne poświęcone historii i krytyce literatury polskiej” 1986, nr 77/2, s. 137.

Foster Hal, Powrót realnego. Awangarda u schyłku XX wieku, Kraków 2010.

Lalak Danuta, Życie jako biografia - podejście biograficzne w perspektywie pedagogicznej, Warszawa 2010.

Levis Richard, Levis Susan, The Power of Art, Thomson Learning, New York 2009. Makselon Józef, Specyfika postaw wobec śmierci, „Studia Philosophiae Christianae” 1981, nr 17/2, s. 121.

Meskimmon Marsha, The Monstrous and the Grotesque: On the Politics of Excess in Women's Self Portraiture, „Make: the Magazine of Women's Art”, październik/listopad 1996, s. 6-11.

Pitrus Andrzej, The Passing: obrazy z soli i pieprzu, „Media - Kultura - Komunikacja Społeczna" 2013, T. 9, s. 167.

Poświatowska Halina, Opowieść dla przyjaciela, Kraków 2009.

Reiter Paulina, Viola Bill, Ludzie nadal trochę boja się sztuki wideo. Rozmowa. [online]. [dostęp 09 maja 2016]. Dostępny w World Wide Web: http:// www.obieg.pl/wydarzenie/2180

Sontag Susan, Choroba jako metafora. AIDS i jego metafory, Kraków 2016.

Spence Jo, Sheard Tim, Narratives of Dis-ease (Exiled) [il.], [w:] The Camerawork Essays: Context and Meaning in Photography, red. Jessica Evans, Sandy Weiland, Barbara Hunt, Londyn 1997, s. 259.

Szalewska Katarzyna, Przestrzeń choroby - miejsce biografii. Kartografia psychosomatyczna w „Opowieści dla przyjaciela” Haliny Poświatowskiej, [w:] Przestrzenie geo(bio)graficzne w literaturze, red. Elżbieta Konończuk, Elżbieta Sidoruk, Białystok 2015.

\section{The therapeutic dimension of art. Overcoming the trauma of illness and death in art and literature - autotherapy of artists on the basis of Jo Spence's photography, Halina Powiatowska's literature and Bill Viola's video}

ABsTRACT: The article concerns the influence of personal traumas of selected artists on the subject taken in artistic works. Author attempts to find an answer to the question whether a person is able to work through a difficult experience 
through art, and what treatments allow a given effect to be obtained. Examples of artists have been selected while meeting two criteria. The first is the experience of the trauma of one's own illness or illness of one's relatives. The second is the use of an artistic form to develop emotions related to biographical facts. Selected artists who met the criteria discussed in this article are Jo Spence, Halina Poświatowska, Bill Viola. Phototherapy and bibliotherapy is the starting point for reflections on the autotherapeutic effects of art and literature. The first is the trauma associated with cancer and the way in which Jo Spence worked it through in his phototherapy. Next, the article discusses attempts to familiarize with heart disease and experiencing the approach of death by the writer Halina Poświatowska. The article ends with examples of the work of Bill Viola, who has undergone an attempt to change and give new meaning to the traumatic experience of losing his mother.

KEYWORDS: bibliotherapy, phototherapy, art, literature, trauma. 